\title{
SARBANES-OXLEY ACT OF 2002: ARE MULTI-NATIONAL CORPORATIONS UNDULY BURDENED?
}

"Sarbanes-Oxley is the most important piece of legislation in the securities area since the New Deal."1

- SEC Commissioner Harvey Goldschmid, 2004

\section{INTRODUCTION}

The Sarbanes Oxley Act (SOX) was signed into law on July 30, 2002. ${ }^{2}$ SOX was enacted in an effort to "restore confidence to the US capital markets." ${ }^{33}$ The frauds of Enron, WorldCom, and other companies prompted Congress to pass legislation to end corruption in American markets. ${ }^{4}$ President Bush, in his speech before signing SOX, stated Corporate America would not be held to a different ethical standard than the rest of the United States. ${ }^{5}$ Even though SOX was enacted to deter corruption in the United States, the impact of the legislation was global. ${ }^{6}$ "Relevant legal developments in the United States ... never go unnoticed in foreign jurisdictions."

\footnotetext{
${ }^{1}$ Harvey Goldschmid, Comm'r, Sec. Exch. Comm'n, Address at Columbia Business School: The Sarbanes Oxley Act: Too Little, Too Far, or Just Enough? (September 17, 2004), available at http://www0.gsb.columbia.edu/leadership/news?\&global.now=09-012004\&main.id=592069\&main.ctrl=contentmgr.detail\&main.view=news.detail.

${ }^{2}$ Bonnie K. Levitt, Sarbanes-Oxley Insider Trading Prohibitions Affect Insiders Outside the US, 14 INT'L CO. \& COM. LAW REV. 293, 293 (2003).

${ }^{3}$ Tom O'Neill, Bertrand Cardi, \& Simon Charbit, Conflicts between French Law and Practice and the US SarbanesOxley Act of 2002, 31 INT'L Bus. LAW. 59, 59 (2003).

${ }^{4}$ Larry E. Ribstein, International Implications of Sarbanes-Oxley: Raising the Rent on U.S. Law 2 (Illinois Law and Economics Working Paper Series, Paper No. LE03-005, 2003), available at http://papers.ssrn.com/pape.tar?abstract_id=401660. [hereinafter Raising the Rent].

${ }^{5}$ George W. Bush, President of the U.S., Address at the signing of the Sarbanes-Oxley Act of 2002 (July 30, 2002), available at http://www.whitehouse.gov/news/releases/2002/07/20020730-1.html.

${ }^{6}$ Jonathan Shirley, Comment, International Law and the Ramifications of the Sarbanes--Oxley Act of 2002, 27 B.C. INT'L \& COMP. L. REV. 501, 511 (2004).

${ }^{7}$ Felix R Ehrat, Sarbanes-Oxley - A View from Outside, 31 InT’L Bus. Law. 75 (2003).
} 
SOX has implications for companies and corporations doing business in the United States and abroad. Firms listed on the New York Stock Exchange are subject to the regulation under United States securities laws. ${ }^{8}$ Approximately fifteen percent of firms listed on the New York Stock Exchange are domiciled outside of the United States. ${ }^{9}$ These companies include the Nokia Corporation domiciled in Finland, ${ }^{10}$ DaimlerChrysler Corporation domiciled in Germany, ${ }^{11}$ and Siemens Corporation also domiciled in Germany. ${ }^{12}$ This is a large group of firms controlled not only by United States securities laws, but also by regulations in their countries of domicile. Problems arise when the regulations under SOX and other United States securities regulations conflict with international corporate governance standards and regulations of individual countries.

This comment examines the conflicts between SOX and corporate governance regulations outside of the United States, specifically in the European Union (emphasizing France and Germany), International Corporate Governance Regulations, and regulations under the World Trade Organization. Section II provides an overview of SOX, the provisions effecting multinational companies, its' background, and the reasoning behind the provisions. Section III discusses the conflicts between the provisions of SOX and international corporate governance. Section IV discusses enforcement issues of both SOX and international corporate governance

\footnotetext{
${ }^{8}$ Raising the Rent, supra note 4 , at 2.

${ }^{9}$ Jordan Siegel, Can Foreign Firms Bond Themselves Effectively by Renting U.S. Securities Laws?, J. OF Fin. ECON., Feb. 2004, at 2, 2, available at http://www.afajof.org/pdfs/2003program/articles/siegel.pdf. This is a chart of the volume of foreign stocks on the New York Stock Exchange. http://www.nysedata.com/factbook/viewer_edition.asp?mode=chart\&key=16\&category=6.

${ }^{10}$ New York Stock Exchange: Listed Company Directory, http://www.nyse.com/about/listed/6.html (last visited Nov. 6, 2005).

${ }^{11}$ New York Stock Exchange: Listed Company Directory http://www.nyse.com/about/listed/6.html?\&ListedComp=All\&start=21\&startlist=1\&item=2\&next=clicked\&firsttim $\mathrm{e}=$ done \&default $=2$ (last visited Nov. 6, 2005).

${ }^{12}$ New York Stock Exchange: Listed Company Directory, http://www.nyse.com/about/listed/6.html?\&ListedComp=All\&start=41\&startlist=1\&item=3\&next=clicked\&firsttim $\mathrm{e}=$ done \&default $=2$ (last visited Nov. 6, 2005).
} 
regulations, including the extraterritorial jurisdiction of the United States as a matter of law and international comity concerns. Section V discusses which form of governance has been more successful and the reasons for success. Section VI is the conclusion.

\section{OVERVIEW OF SOX AND ITS PROVISIONS}

\section{A. Background of SOX}

SOX was enacted in the wake of Enron, WorldCom, and other business scandals in the United States. ${ }^{13}$ Politicians feared the scandals would cripple American markets. ${ }^{14}$ The scandals had already resulted in billions of dollars of corporate losses and deeply harmed investor trust. ${ }^{15}$ Congress realized if they did not take swift action, the problem would spread throughout every sector of the economy. ${ }^{16}$ Congress felt most of the links in the chain, such as managerial controls for disclosure and between auditors and officers of a company, had failed and companies failed to deliver clean and honest information to investors. ${ }^{17}$

The Bush Administration was under immense pressure to push for a tough response of regulation after the Enron scandal. ${ }^{18}$ The explosion of the Enron scandal in the media led to over thirty "Enron-inspired" bills being contemplated on by Congress. ${ }^{19}$ By July 25, 2004, a final bill was passed by Congress and was signed into law by President Bush five days later. ${ }^{20}$

\footnotetext{
${ }^{13}$ Michael A. Perino, American Corporate Reform Abroad: Sarbanes-Oxley and the Foreign Private Issuer, 4 EuR. BUS. ORG. L. REV. 213 (2003), available at http://papers.ssrn.com/sol3/papers.cfm?abstract_id=439501. 
The scandals occurred because monitoring failed at several levels, including the monitoring of directors and at prominent accounting and law firms. ${ }^{21}$ SOX requires all publiclytraded companies, domestic and multinational companies, to comply with regulations set out in the Act. $^{22}$ SOX regulations try to improve corporate governance and corporate accountability by requiring honesty in financial reporting. ${ }^{23}$

\section{B. Provisions of SOX}

SOX includes provisions to "restore integrity to financial markets and confidence in corporate conducts, financial reports and related audit functions." ${ }^{24}$ It creates new rules to "protect auditor independence and address conflicts of interest faced by securities analysts." 25 The provisions range from accounting procedures and enhanced disclosure to criminal sanctions for violating the regulations of SOX. ${ }^{26}$ These provisions have the goal of trying to get honest and detailed information to investors, without the taint of corruption or deceit.

\section{Title III: Corporate Responsibility ${ }^{27}$}

Sections 301 to 308 lay out the requirements for corporate responsibility under SOX. ${ }^{28}$ There are four relevant provisions under Title III: (1) the establishment of audit committees of public companies, $;^{29}$ (2) CEO and CFO certifications; ${ }^{30}$ (3) insider trades during pension fund blackout periods $;{ }^{31}$ and (4) the rules of professional conduct for attorneys. ${ }^{32}$

\footnotetext{
${ }^{21}$ Raising the Rent, supra note 4, at 2.

${ }^{22}$ Information Guide, supra note 15.

${ }^{23}$ Pankaj K. Jain \& Zabihollah Rezaee, Professors, U. of Mem., 2003 Financial Management Association Meeting, Denver, Colorado: Have the Sarbanes Oxley Act of 2002 and CEO Certifications Made the Markets More Informed? (Oct. 8, 2003), available at http://207.36.165.114/Denver/Papers/sarbanes_spread.pdf.

${ }^{24} I d$.

${ }^{25}$ William H. Donaldson, Chairman, Sec. Exchange Comm'n, Address at London School of Economics: U.S. Capital Markets in the Post-Sarbanes-Oxley World: Why Our Markets Should Matter to Foreign Issuers (Jan. 25, 2005).

${ }^{26}$ Ehrat, supra note 7 , at 75

${ }^{27}$ Sarbanes--Oxley Act of 2002, Pub. L. No. 107--204, § 307, 116 Stat. 745 (2002) (codified as amended in 15 U.S.C.A. $§ \S 7201-7266$ and scattered sections of 11,18,28, and 29 U.S.C.A. (West Supp. 2003), available at http://news.findlaw.com/hdocs/docs/gwbush/sarbanesoxley072302.pdf [hereinafter The Act].

${ }^{28}$ PRACTICAL GUIDE, supra note 17 , at 301.
} 


\section{a. Section 301: Public Company Audit Committees ${ }^{33}$}

The audit committees of public companies must be made up of independent directors. ${ }^{34}$ The requirements for the directors include taking charge of corporate audits and overseeing the auditors, resolving accounting disputes between auditors and management, and hearing and acting on complaints regarding accounting or internal control issues. ${ }^{35}$ The members of the audit committee must be independent; this means thatthe members cannot receive any kind of compensation for advising or consulting from the issuer and must not be affiliated with the issuer. $^{36}$

The purpose of this provision is to ensure the independence of auditors from management. ${ }^{37}$ Congress realized before the enactment of SOX that many problems were due to "close ties between audit committee members and management." ${ }^{38}$ The audit committee cannot owe their loyalty to the management of the company; it must be loyal to the company as a whole and the committee. ${ }^{39}$

\section{b. Section 302: Corporate Responsibility for Financial Reports ${ }^{40}$}

Chief Financial Officers (CFOs) and Chief Executive Officers (CEOs) are required to certify that the financial statements are truthful and contain no material misstatements. ${ }^{41}$ The statement shows the company has the required internal control overfinancial $\mathrm{r}$ eporting and

\footnotetext{
${ }^{29}$ PRACTICAL GUIDE, supra note 17 , at 301 .

${ }^{30} \mathrm{Id}$. at 311.

${ }^{31} \mathrm{Id}$. at 327.

${ }^{32}$ Id. at 339.

33 The Act, supra note 27, § 301.

${ }^{34}$ PRACTICAL GUIDE, supra note 17 , at 301.

${ }^{35} \mathrm{Id}$.

${ }^{36} I d$. at 305.

${ }^{37} \mathrm{Id}$. at 302 .

${ }^{38} \mathrm{Id}$. at 301.

${ }^{39}$ Id. at 302.

${ }^{40}$ The Act, supra note $27, \S 302$.

${ }^{41}$ PRACTICAL GUIDE, supra note 17 , at 311.
} 
disclosure procedures. $^{42}$ Statements that must be certified under this section are forms $10-\mathrm{Q}, 10$ $\mathrm{K}, 20-\mathrm{F}$, and $40-\mathrm{F}^{43}$

The 10-Q is a report filed quarterly to the Securities and Exchange Commission (SEC). ${ }^{44}$ It includes an unaudited financial statement and shows the financial status of the firm. ${ }^{45}$ The report must be filed for the first three fiscal quarters and is due within 45 days of the end of the quarter. $^{46}$ The $10-\mathrm{K}$ provides a comprehensive outline of the firm's business. ${ }^{47}$ The report must be filed within 90 days of the end of the fiscal year. ${ }^{48}$ The $20-\mathrm{F}$ is the form for foreign private issuers to register with the SEC under Section 12(b) or 12(g) of the Securities Exchange Act of $1934{ }^{49}$ It is also the form used for annual and transition reports for firms under Sections 13 and 15(d) of the Securities Exchange Act of $19344^{50}$ The 40-F is a registration statement under Section 12 of the Securities Exchange Act of 1934 or an annual report under Section 13(a) or 15(d) of the Securities Exchange Act of $1934 .^{51}$

Section 302 of SOX requires CEOs and CFOs to certify financial reports and requires officers to review and verify that the reports are honest and do not contain misleading or false statements. ${ }^{52}$ This section requires certification to cover "review of the report, its material accuracy, the fair presentation of financial information, disclosure controls, and internal

\footnotetext{
${ }^{42}$ PRACTICAL GuIDE, supra note 17 , at 311.

${ }^{43} I d$. at 312.

${ }^{44}$ Definition of 10-Q, http://www.accounting-career-opportunity.com/accounting-terms-and-definition.html (last visited Nov. 6, 2005).

${ }^{45} I d$.

${ }^{46} I d$.

${ }^{47}$ Definition of 10-K, http://www.accounting-career-opportunity.com/accounting-terms-and-definition.html (last visited Nov. 6, 2005).

${ }^{48} I d$.

${ }^{49}$ Security Lawyer's Deskbook, http://www.law.uc.edu/CCL/34forms/form20-F.html (last visited Nov. 6, 2005).

${ }^{50} I d$.

${ }^{51} I d$.

${ }^{52}$ Practical Guide, supra note 17 , at 311.
} 
accounting controls." ${ }^{, 53}$ CEOs and CFOs are held accountable for the financial statements and must sign the reviewed financial documents. ${ }^{54}$

\section{c. Section 306: Insider Trades During Pension Fund Blackout Periods ${ }^{55}$}

Corporate officers and directors are not allowed to trade in company stock during a "blackout period."56 A blackout period is a "period of at least three days during which at least half of the company's U.S. individual account plan participants are not permitted to trade the company stock within their plans." ${ }^{57}$ Participants also receive at least 30 days notice prior to a blackout period. ${ }^{58}$

This provision emerged directly from the Enron scandal, where it was alleged that “employees held Enron stock in their individual retirement account plans and were prevented from selling the stock on account of a 'blackout'", and during that time their stock lost value. ${ }^{59}$ This provision only applies to issuers who maintain individual account plans. ${ }^{60}$

d. Section 307: Rules of Professional Responsibility for Attorneys ${ }^{61}$

Attorneys are required to report evidence of securities violations and any other fraudulent act to a company's chief counsel or the CEO. ${ }^{62}$ The attorney must take the evidence to the board of directors if appropriate action is not taken. ${ }^{63}$ This process is known as "up-the-ladder

\footnotetext{
${ }^{53}$ GUY P. LANDER, WHAT IS SARBANES-OXLEY? 4 (2004).

${ }^{54}$ PRACTICAL GUIDE, supra note 17 , at 311.

55 The Act, supra note $27, \S 306$.

${ }^{56}$ PRACTICAL GUIDE, supra note 17 , at 327.

${ }^{57} \mathrm{Id}$.

${ }^{58} \mathrm{Id}$.

${ }^{59} I d$.

${ }^{60} \mathrm{Id}$. at 328.

${ }^{61}$ The Act, supra note 27, $\$ 307$.

${ }^{62}$ PRACTICAL GUIDE, supra note 17 , at 339.

${ }^{63} \mathrm{Id}$.
} 
reporting." ${ }^{64}$ The attorney has discretion to decide whether or not the company has appropriately responded to the report. ${ }^{65}$

The purpose of this provision is to hold attorneys accountable to the same standards as officers of a company. ${ }^{66}$ The attorney "owes his or her professional and ethical duties to the company as an organization, rather than to the company's officers, directors, or employees.",67 Congress felt thatprevious regulations on attorneys were ineffective and did not deter attorney wrongdoing. ${ }^{68}$ This provision requires attorneys to report any material violation and be held accountable for not reporting violations. ${ }^{69}$

There is also a provision in this section labeled the "noisy withdrawal" regulation. ${ }^{70}$ This provision arises when the attorney does not receive a timely response to a report citing a material violation. ${ }^{71}$ The procedure differs for external attorneys working on a matter for a corporation and in-house attorneys working directly for the corporation. An external attorney must withdraw from representing the corporation and notify in writing thatthe withdrawal is based on professional considerations. ${ }^{72}$ An in-house attorney must stop working on the matter concerning the violation and notify the corporation in writing that there has not been an adequate response to their report. $^{73}$

\section{Title IV: Enhanced Financial Disclosures ${ }^{74}$}

\footnotetext{
${ }^{64}$ PRACTICAL GUIDE, supra note 17 , at 340.

${ }^{65} \mathrm{Id}$. at 340.

${ }^{66} \mathrm{Id}$. at 339.

${ }^{67}$ LANDER, supra note 53, at 91.

${ }^{68}$ PRACTICAL GUIDE, supra note 17, at 339.

${ }^{69} \mathrm{Id}$. at 340 .

${ }^{70} \mathrm{Id}$. at 345.

${ }^{71} \mathrm{Id}$.

${ }^{72} I d$.

${ }^{73} \mathrm{Id}$.

${ }^{74}$ The Act, supra note $27, \S 400$.
} 
Sections 401 to 409 lay out the requirements for financial disclosures under SOX. ${ }^{75}$

There are three relevant sections under Title IV: (1) the management assessment of internal controls $;{ }^{76}(2)$ the code of ethics for senior financial officers $;{ }^{77}$ and (3) real-time issuer disclosures. $^{78}$

\section{a. Section 404: Management Assessment of Internal Controls ${ }^{79}$}

Annual reports of a public company are to be accompanied by a report on the effectiveness of internal control. ${ }^{80}$ Auditors are required to attest to management's assessment of internal control. ${ }^{81}$ Management is responsible for ensuring thatthe internal control meets the requirements under SOX. ${ }^{82}$ These requirements include designing a system of internal control, supervised operation of the system, continuous monitoring of the system, and documentation of the internal controls implemented. ${ }^{83}$ The independent auditor of a company must also report on the company's internal control over financial reporting. ${ }^{84}$ If the auditors cannot express an overall opinion about the effectiveness of a company's internal control over financial reporting, the auditors must explain why. ${ }^{85}$ The management assessment of internal controls and also the auditor's assessment must be included in the annual report. ${ }^{86}$

The purpose of this provision is to assure investors thatcompanies have an effective internal control system. ${ }^{87}$ Before SOX, it was rare for companies to report on internal control. ${ }^{88}$

\footnotetext{
${ }^{75}$ PRACTICAL GUIDE, supra note 17 , at 401.

${ }^{76} I d$. at 418 .

${ }^{77}$ Id. at 427.

${ }^{78}$ Id. at 436.

${ }^{79}$ The Act, supra note 27, $\$ 404$.

${ }^{80}$ PRACTICAL GUIDE, supra note 17 , at 418.

${ }^{81}$ Id.

${ }^{82} \mathrm{Id}$. at 421.

${ }^{83} \mathrm{Id}$. at 1603 .

${ }^{84} \mathrm{Id}$. at 423 .

${ }^{85}$ LANDER, supra note 53, at 19.

${ }^{86}$ Amey Stone, Hardly Ready for Sarbanes-Oxley, BUS. WK., Sept. 20, 2004.

${ }^{87}$ PRACTICAL GUIDE, supra note 17 , at 419.

${ }^{88}$ Id.
} 
This section holds management accountable for the internal control of a company and makes it public knowledge so investors know there is an internal control mechanism in place. ${ }^{89}$ It also places a burden on the auditors of a company to report on the internal control procedures and their effectiveness. ${ }^{90}$

\section{b. Section 406: Code of Ethics for Senior Financial Officers ${ }^{91}$}

Companies must disclose whether it has adopted a code of ethics for financial officers. ${ }^{92}$ For purposes of the provision, a code of ethics must be a written set of standards deterring violations and promoting honest conduct. ${ }^{93}$ Companies must include the code of ethics in their annual report. 94

This provision shows investors whether a company has a written set of rules for financial officers. $^{95}$ A company may also have different codes of ethics for different types of employees. ${ }^{96}$ The code may be part of a larger code addressing other issues and applying to additional persons. $^{97}$ If a company does not have a code of ethics for financial officers, the company must state the reasons why they have not adopted a code. ${ }^{98}$ Also, if a company's code of ethics is defective, they may not affirm thatit has the required code. ${ }^{99}$ A company must also report any change to the code and keep it updated. ${ }^{100}$

c. Section 409: Real-time Issuer Disclosures ${ }^{101}$

\footnotetext{
${ }^{89}$ PRACTICAL GUIDE, supra note 17 , at 420 .

${ }^{90} \mathrm{Id}$. at 423.

${ }^{91}$ The Act, supra note 27, § 406.

${ }^{92}$ PRACTICAL GUIDE, supra note 17, at 427.

${ }^{93}$ Id. at 428 .

${ }^{94} \mathrm{Id}$.

${ }^{95} \mathrm{Id}$. at 427.

${ }^{96}$ LANDER, supra note 53, at 66.

${ }^{97}$ Id.

${ }^{98}$ PRACTICAL GUIDE, supra note 17 , at 427.

${ }^{99}$ LANDER, supra note 53, at 65.

${ }^{100}$ PRACTICAL GUIDE, supra note 17 , at 427.

101 The Act, supra note 27, § 409.
} 
The SEC is "required to issue rules requiring 'real-time' disclosure of a number of key occurrences and transactions, which may be of importance to investors."102 Issuers are required to disclose, in real-time, material changes and transactions. ${ }^{103}$ Events prompting the disclosure requirements have to be reported within two business days. ${ }^{104}$ The disclosure must also be in English, it cannot be submitted in any other language even if a corporation is domiciled outside of the United States. ${ }^{105}$

The purpose of this provision is to disclose information of material changes of the financial condition of the company in a timely fashion. ${ }^{106}$ This leads to a constant flow of current information. This provision is "necessary ... for the protection of investors and in the public interest.",107

\section{Title VIII: Corporate and Criminal Fraud Accountability ${ }^{108}$}

Sections 801 to 807 lay out the punishment for violation of other provisions of SOX. ${ }^{109}$ A relevant provision under Title VIII deals with protection for employees who provide evidence of fraud. ${ }^{110}$

a. Section 806: Protection for Employees of Publicly Traded Companies Who Provide Evidence of Fraud ${ }^{111}$

This provision encourages "whistleblowing" by employees who report any violation of SOX. ${ }^{112}$ It also prohibits companies from retaliating against employees who have reported

\footnotetext{
102 PRACTICAL GUIDE, supra note 17, at 436.

${ }^{103}$ Id. at 438.

${ }^{104}$ Id. at 436 .

${ }^{105} \mathrm{Id}$.

${ }^{106} \mathrm{Id}$.

${ }^{107} \mathrm{Id}$.

108 The Act, supra note 27, 8800.

${ }^{109}$ PRACTICAL GUIDE, supra note 17 , at 801.

${ }^{110} \mathrm{Id}$.

${ }^{111}$ The Act, supra note 27, § 806.

${ }^{112}$ PRACTICAL GUIDE, supra note 17 , at 811 .
} 
securities law violations. ${ }^{113}$ This section can be implemented under Section 301, which requires audit committees to hear and act on reports of violations. ${ }^{114}$ The audit committee must have procedures to receive complaints regarding internal accounting measures and auditing issues. ${ }^{115}$

The committee must also set up a system to receive anonymous submissions by employees concerning question accounting and auditing procedures. ${ }^{116}$ All reports of violations are kept confidential. ${ }^{117}$

The purpose of this provision is to protect employees from being wrongfully terminated or disciplined for reporting violations. ${ }^{118}$ The employee has recourse if the company does take retaliatory action. The employee can file a complaint with the Department of Labor and if the matter is not resolved within 80 days, the employee may file a suit against the company in federal court. ${ }^{119}$

\section{Title IX: White-Collar Crime Penalty Enhancements ${ }^{120}$}

Sections 901 to 906 describe the criminal sanctions imposed on individuals within corporations who ignore the regulations of SOX. ${ }^{121}$ A relevant provision under Title IX of SOX deals with corporate responsibility for financial reports. ${ }^{122}$

a. Section 906: Corporate Responsibility for Financial Reports ${ }^{123}$

CEOs and CFOs are required to certify financial statements to comply with SOX. ${ }^{124}$ This provision requires "that financial statements comply with SEC reporting rules and that the

\footnotetext{
${ }^{113} \mathrm{Id}$.

${ }^{115}$ Id. at 308 .

${ }^{116} \mathrm{Id}$.

${ }^{117} I d$. at 811 .

${ }^{118}$ Id. at 812 .

${ }^{119} \mathrm{Id}$. at 811 .

${ }^{120}$ The Act, supra note 27, § 900.

${ }^{121}$ PRACTICAL GUIDE, supra note 17 , at 901.

${ }^{122}$ Id. at 904 .

123 The Act, supra note 27, § 906.
}

${ }^{114}$ PRACTICAL GUIDE, supra note 17, at 811. Each audit committee must "establish procedures for: (1) the receipt, retention, and treatment of complaints received by the listed issuer . . . and (2) the confidential, anonymous submission by employees . . of concerns regarding questionable accounting or auditing matters." Id at 308. 
statements fairly present, in all material respects, the financial condition and results of operations of the company."125 This section states the penalties for not complying with section 906 and also Section $302 .^{126}$ The penalty imposed for certification of statements that officers know to be inaccurate includes imprisonment and monetary fines. ${ }^{127}$

The certification must accompany periodic financial statements submitted to the SEC. ${ }^{128}$

The periodic statements included under this section are forms 10-K, 10-Q, 20-F, and 40-F, which were defined earlier. ${ }^{129}$ Section 906 also makes it easier for prosecutors to build a case against executives who issue false or misleading financial statements. ${ }^{130}$ Section 906 is called the "criminal" certification for CEOs and CFOs. ${ }^{131}$

\section{SOX: CONFLICTS WITH INTERNATIONAL LAW}

SOX has implications for companies doing business in the United States and abroad. ${ }^{132}$ However, only companies listed on United States exchanges are affected. ${ }^{133}$ "More than 1300 foreign corporations that list securities on U.S. exchanges are affected."134 Not all provisions of SOX conflict with international corporate governance, but there are many provisions that do.

\section{A. Sections of SOX Conflicting with International Law}

\footnotetext{
${ }^{124}$ PRACTICAL GUIDE, supra note 17 , at 904.

125 PRACTICAL GUIDE, supra note 17, at 904.

${ }^{126} \mathrm{Id}$.

${ }^{127}$ Id. A person who certifies a financial statement knowing that the report accompanying the financial statement does not comply with the regulations under this provision will be fined no more than 1 million dollars and imprisoned for not more than 10 years, or both. Id at 905. A person who willfully certifies a financial statement knowing the report does not comply with the requirements under this provision will be fined no more than 5 million dollars or imprisoned for not more than 20 years, or both. Id at 905 .

${ }^{128}$ LANDER, supra note 53, at 8.

${ }^{129} \mathrm{Id}$.

${ }^{130}$ PRACTICAL GUIDE, supra note 17, at 904.

${ }^{131}$ LANDER, supra note 53, at 8.

${ }^{132}$ Shirley, supra note 6, at 511.

${ }^{133}$ Id.

${ }^{134} \mathrm{Id}$.
} 
Section 301 of SOX deals with the formation of public company audit committees and who comprises them. ${ }^{135}$ This provision makes it difficult for foreign companies, most of who are controlled by few shareholders. ${ }^{136}$ The audit committee must be staffed by completely independent members. ${ }^{137}$

This requirement of independent members on the audit committee raises problems for many companies. For companies who are controlled by a few large shareholders, SOX excludes major shareholders who may insist on more of a voice in the audit committee. ${ }^{138}$ In a foreign company, one member may represent majority shareholders as an observer. ${ }^{139}$

The formation of an audit committee may also lead to unnecessary expenses for firms with only one or a few controlling shareholders. ${ }^{140}$ In this type of firm, the main problem is “controlling shareholders' oppression of minority shareholders rather than managerial agency costs." ${ }^{141}$ The independent audit committee is valuable in helping shareholders judge management by ensuring quality auditing of the firm. ${ }^{142}$ Differences in the quality of auditing are likely to be ineffective against shareholder opportunism. ${ }^{143}$ These additional decisionmaking costs are likely to outweigh the benefits in multinational firms. ${ }^{144}$ The costs are based on the increased amount of time it takes to file the relevant forms and also firms who accrue additional outside professional costs. ${ }^{145}$

\footnotetext{
${ }^{135}$ PRACTICAL GuIDE, supra note 17, at 301.

${ }^{136}$ Raising the Rent, supra note 4, at 28.

${ }^{137} \mathrm{Id}$.

${ }^{138} I d$. at 9 .

${ }^{139} \mathrm{Id}$.

${ }^{140} I d$. at 10.

${ }^{141} I d$. at 10.

${ }^{142}$ Raising the Rent, supra note 4, at 10.

${ }^{143}$ Id. at 10.

${ }^{144} I d$. at 10.

145 Estelle M. Sohne, The Impact of Post--Enron Information Disclosure Requirements Imposed Under U.S. Law on Foreign Investors, 42 COLUM. J. TRANSNAT'L L. 217, 230 (2003).
} 
Section 301 can directly conflict with laws of many countries, especially those countries who have a civil law system. ${ }^{146}$ Many countries with civil law systems, including France and Germany, require "two-tier" boards. ${ }^{147}$ The "upper" board (supervisory board) must be at least half comprised of labor managers and the "lower" board (managing board) is typically comprised of insider executives. ${ }^{148}$ The requirement also creates conflicts with the status of internal and external auditors. ${ }^{149}$ In Italy, Japan, and Brazil, the local laws provide "for a statutory board of auditors that must be independent of the board of directors itself (thus precluding an audit committee comprised of 'independent directors')". ${ }^{150}$ French companies are regulated by "two independent institutes, the Ordre des Experts-Comptables (National Institute for Chartered Accountants) and the Compagnie Nationale des Commissaires aux Comptes (National Institute for Statutory Auditors)." ${ }^{151}$ French companies wonder why they have to abide by the regulations of SOX and also regulations under French oversight boards. ${ }^{152}$ It is standard practice in most European countries for shareholders to directly appoint outside auditors, not by a special committee of independent directors. ${ }^{153}$

Civil law corporations have generally resisted giving the supervisory board important substantive responsibilities, because employee representatives serve on the board. ${ }^{154}$ Under SOX, labor representatives would be given great responsibility, because "the audit committee

\footnotetext{
${ }^{146}$ Kenji Taneda, Survey: Sarbanes-Oxley, Foreign Issuers and United States Securities Regulation, 2003 Colum. BUS. L. REV. 715, 739 (2003).

${ }^{147} I d$. at 739.

${ }^{148} I d$.

${ }^{149} I d$.

${ }^{150} \mathrm{Id}$.

${ }^{151}$ John Paul Lucci, Enron - The Bankruptcy Heard Around the World and the International Ricochet of SarbanesOxley, 67 ALB. L. REV. 211, 240 (2003).

${ }^{152}$ Id. at 240.

${ }^{153}$ Taneda, supra note 146 , at 739.

${ }^{154}$ Minodora D. Vancea, Exporting U.S. Corporate Governance Standards through the Sarbanes-Oxley Act: Unilateralism or Cooperation?, 53 DUKE L. J. 833 (2001), available at http://www.law.duke.edu/journals/dlj/articles/dlj53p833.htm.
} 
must be staffed with members of the supervisory committee, including labor representatives." ${ }^{\prime 155}$ The conflict between SOX and a civil system of government also makes it impossible for companies in those countries to "comply with both the codetermination requirement imposed by their country of incorporation and the independence requirement imposed by the Sarbanes-Oxley Act."156 Most members of the supervisory board, required under codetermination, are not considered independent under United States law. ${ }^{157}$ The SEC does have an exemption for this circumstance, but foreign companies are uneasy about increasing labor representatives' bargaining power. $^{158}$

Section 302 of SOX ensures corporate responsibility by requiring CEOs and CFOs to certify financial statements published by a company. ${ }^{159}$ This provision has caused immediate concern, especially in European companies. ${ }^{160}$ There are no corresponding requirements in English or Swiss law. ${ }^{161}$ In French law, it is only the CEO who certifies financial statements and not the CFO. ${ }^{162}$ In Germany, corporations have the governance structure of two tiers consisting of a management board, Vorstand, and a supervisory board, Aufsichstrat. ${ }^{163}$ The executive with responsibilities most analogous to the CEO of an American company is a member of the

${ }^{155}$ Vancea, supra note 154 , at 841.

${ }^{156} \mathrm{Id}$.

${ }^{157} 17$ C.F.R. $\S 240.10$ A-3(b)(1), available at http://a257.g.akamaitech.net/7/257/2422/12feb20041500/edocket.access.gpo.gov/cfr_2004/aprqtr/pdf/17cfr240.10A3.pdf. "Each member of the audit committee must be a member of the board of directors of the listed issuer." Id. "An affiliate of the company is not independent for audit committee purposes." Vancea, supra note 154, n.47. "An affiliate is defined as someone that 'controls, or is controlled by, or is under common control with' the company." Id.

${ }^{158}$ Vancea, supra note 154 , at 842 . The exemption is that foreign employee representatives on the supervisory board are allowed to be part of the audit committee, even though they are not independent of the company's executives. Id.

${ }^{159}$ PRACTICAL GUIDE, supra note 17 , at 311.

${ }^{160}$ Mark Walsh \& Thomas Thesing, Extraterritorial Application of US Corporate Governance Standards in Europe, 14 INT'L Co. \& COM. L. REV. 165, 165 (2003).

${ }^{161} \mathrm{Id}$. at 165 .

162 Tom O'Neill, Bertrand Cardi, \& Simon Charbit, Conflicts between French Law and Practice and the US Sarbanes-Oxley Act of 2002, 31 INT'L BuS. LAW. 59, 59 (2003).

${ }^{163}$ Letter from Cleary, Gottleib, Steen, \& Hamilton Law Firm, to Jonathan G. Katz, Secretary, Sec. Exch., Comm'n (August 19, 2002) (on file with the Sec. Exch. Comm'n), available at http://www.sec.gov/rules/proposed/s72102/cleary1.htm. 
management board. ${ }^{164}$ There is also not a member of the management board who all other employees and executives report to and are subordinate to. ${ }^{165}$ The members of the management board represent the company equally. ${ }^{166}$

The requirement of $\mathrm{CEO}$ and $\mathrm{CFO}$ certification creates problems with firms operating outside of the United States, primarily because the process of certification can be time consuming. ${ }^{167}$ Executives of many foreign issuers are greatly disadvantaged, because they are not accustomed to United States disclosure standards and practices. ${ }^{168}$ An example of the disadvantage can be seen in the "materially accurate" standard for certification of financial statements under section 302. ${ }^{169}$ Materiality is a concept central to United States securities laws, but foreign firms are unsure of the standard and if it has been met. ${ }^{170}$ In countries of the European Union (EU), the term "price sensitive" is used, but this is only a similar standard, not an exact one. ${ }^{171}$ The SEC has made an exception for foreign firms so they only have to make this certification once annually. ${ }^{172}$ This provision is not burdensome for sophisticated foreign firms, but for all others it can be very burdensome. ${ }^{173}$

Section 306 regulates insider trades during pension fund blackout periods. ${ }^{174}$ "When blackouts affect a significant percentage of US participants in certain retirement plans, than all

\footnotetext{
${ }^{164}$ Letter from Cleary, Gottleib, Steen, \& Hamilton Law Firm to Jonathan G. Katz, supra note 163.

${ }^{165} \mathrm{Id}$.

${ }^{166} I d$.

${ }^{167}$ Michael P. Kelley, The Impact of Sarbanes-Oxley on Foreign Private Issuers, Private Equity Funds and Their Counsel, VA. L., April 2003, at 24, 25, available at http://www.vsb.org/publications/valawyer/apr03/kelley.pdf.

${ }^{168}$ Tod Ackerly, The Global Impact of U.S. Corporate Governance Initiatives, CovingTON \& BURLING, Oct. 2002, available at http://www.cov.com/publications/download/oid43940/314.pdf.

${ }^{169}$ Ackerly, supra note 168. See 15 U.S.C.A $\$ 78$ a; 17 C.F.R. Section 240.18a (West, Westlaw through Sept. 205 amendments).

${ }^{170}$ Ackerly, supra note 168.

${ }^{171}$ Ackerly, supra note 168. See Council Directive 98/34, art. 21.7.98, 1998 O.J. (L 204) (EC), available at http://europa.eu.int/comm/enterprise/tris/98_34_ec/index_en.pdf.

${ }_{172}$ Ackerly, supra note 168.

${ }^{173}$ Kelley, supra note 167, at 25.

${ }^{174}$ PRACTICAL GUIDE, supra note 17, at 327.
} 
trading by insiders, including insiders of the non-US issuer, is prohibited." ${ }^{\prime 75}$ This provision specifically applies to multinational corporations as well as domestic corporations. Foreign private issuers, for the purposes of this section, are defined as any foreign private issuer other than a foreign government and having more than fifty per cent of the issuer's outstanding voting securities directly or indirectly held by residents in the United States. ${ }^{176}$ The test applied to a foreign issuer is more stringent than the test applied to domestic corporations. ${ }^{177}$

The test applied to corporations under this provision is the fifty per cent test. ${ }^{178}$ This test is applied by comparing "the number of affected participants and beneficiaries located within the United States and its territories who will be restricted with the total number of participants and beneficiaries in all of the issuer's relevant US individual account plans." ${ }^{\prime 19}$ Foreign corporations are also subjected to an additional test. The additional test is a calculation made to confirm either that at least fifteen per cent of the beneficiaries and participants in the corporation's relevant worldwide individual account plans are affected by the blackout and more than 50,000 United States plan participants are affected. ${ }^{180}$ Also, for the purpose of foreign corporations, the definition of a "director" is limited to directors who are also management employees. ${ }^{181}$

Section 307 requires attorneys to report any security violations to the company, so that the situation may be resolved. ${ }^{182}$ This provision affects attorneys practicing in the United States, but also applies to any attorney outside the United States working for multinational firms falling under SOX regulations, unless the attorney falls under any of the exceptions listed in the

\footnotetext{
${ }^{175}$ Levitt, supra note 2, at 293.

${ }^{176}$ Id. at 294.

${ }^{177}$ Id. at 295.

${ }^{178} \mathrm{Id}$.

${ }^{179} \mathrm{Id}$.

${ }^{180} \mathrm{Id}$

${ }^{181}$ Levitt, supra nte 2, at 295.

${ }^{182}$ PRACTICAL GUIDE, supra note 17, at 339.
} 
section. ${ }^{183}$ The SEC, after receiving many complaints from multinational firms, included a definition for "non-appearing foreign attorney" which excludes most lawyers who do not practice in the United States. ${ }^{184}$ Non-appearing foreign attorneys are attorneys who are admitted to practice law outside of the United States, do not hold themselves out as giving advice on or practicing American law, and conduct activities that are incidental to a foreign law practice or in consultation with United States counsel. ${ }^{185}$ The rule, however, does not apply when foreign attorneys are rendering their advice when consulting with counsel practicing in the United States. $^{186}$

The provisions for regulating attorneys under SOX may conflict with international rules and rules of individual countries. ${ }^{187}$ In Germany, secrecy is mandated not only by the professional rules but also by the penal code. ${ }^{188}$ Another problem faced by attorneys of multinational corporations is thatattorneys that practice law outside of the United States may be unfamiliar with violations of United States securities laws. ${ }^{189}$ How can the SEC expect foreign attorneys to report material violations of United States securities laws if they lack expertise in that area of law? ${ }^{190}$ Foreign firms also argue the "noisy withdrawal" provision may constitute a breach of attorney-client privilege. ${ }^{191}$ The SEC does try to alleviate some of the concerns of multinational corporations and foreign issuers by excluding most foreign attorneys, not licensed

\footnotetext{
${ }^{183}$ PRACTICAL GUIDE, supra note 17 , at 340.

${ }^{184}$ Walsh \& Thesing, supra note 160 , at 170.

${ }^{185}$ Robert D. Strahota, Assistant Dir., Off. of Int'l Aff., Sec. Exch. Comm'n, Address at the Fourth South Eastern Europe Corporate Governance Roundtable: Recent Governance Developments in the United States (March 7, 2003), available at http://www.oecd.org/dataoecd/46/54/2506071.ppt.

${ }^{186}$ Walsh \& Thesing, supra note 160 , at 170.

${ }^{187}$ Detlev F. Vagts, Extraterritoriality and the Corporate Governance Law, 97 AM. J. INT'L L. 289 (2003).

${ }^{188}$ Id. at 293.

${ }^{189}$ Ethiopos Tafara, Acting Dir., Off. of Int'l Aff., Sec. Exch. Comm'n., Address before the American Chamber of Commerce in Luxembourg: Addressing International Concerns under the Sarbanes-Oxley Act (June 10, 2003), available at http://www.sec.gov/news/speech/spch061003et.htm. 
to practice law in the United States, from its coverage. ${ }^{192}$ "As a general matter, only foreign attorneys who provide advice regarding US securities law may still be subject to the rule."193

Section 404 regulates management's assessment of internal controls. ${ }^{194}$ SOX makes no distinction between corporations that are completely domestic and multinational corporations doing business in the United States and abroad. ${ }^{195}$ There is a later compliance date for multinational corporations, but that is the only dissimilarity in the rule. ${ }^{196}$ Many executives of multinational firms are unhappy with Section 404 of SOX. According to a survey conducted by PricewaterhouseCoopers in June of 2003, only thirty percent of executives of multinational corporations had a favorable opinion of the provision. ${ }^{197}$

This provision has many implications for multinational corporations. Before SOX, management was not required to have extensive internal control expertise. ${ }^{198}$ The business environments in certain regions are less focused on controls; examples include Asia, Latin America, and Europe. ${ }^{199}$ This lack of expertise and focus leads to an increase in the amount of work needed to comply with Section 404 of SOX. ${ }^{200}$

Another problem for multinational corporations is the form of the organization. Multinational corporations have a "decentralized organizational model."201 This type of corporation may only receive financial statements from their subsidiaries once or twice a year

\footnotetext{
192 Tafara, supra note 189.

${ }^{193}$ Id.

${ }^{194}$ PRACTICAL GUIDE, supra note 17 , at 418.

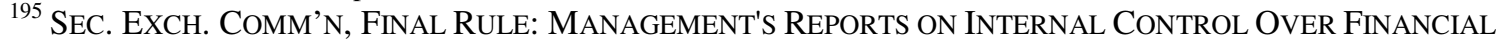
REPORTING AND CERTIFICATION OF DisClOSURE IN EXCHANGE ACT PERIODIC REPORTS (2003).

${ }^{196} \mathrm{Id}$.

${ }^{197}$ WARREN GORHAM \& LAMONT, How MultinAtional COMPANIES ARE RESPONDING TO THE SARBANES-OXLEY ACT (2003).

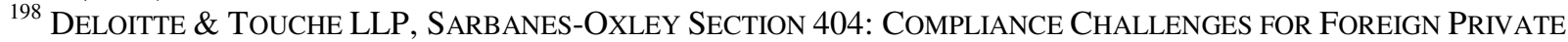
ISSUERS 5, available at http://www.iasplus.com/dttpubs/0502soxfpi.pdf.

199 Id. at 5 .

${ }^{200} \mathrm{Id}$.

${ }^{201} I d$. at 4. Multinational corporations usually have subsidiaries in different countries. Id.
} 
making it very difficult for these corporations to report to the SEC in a timely fashion. ${ }^{202}$ There are also language barriers to consider when having to report to the SEC. ${ }^{203}$ Many corporations have found that the English language is not always an effective medium of communication. ${ }^{204}$

SOX also requires corporations to use Generally Accepted Accounting Principles (GAAP). ${ }^{205}$ Section 108 of SOX requires corporations to use GAAP standards when preparing financial statements. ${ }^{206}$ Traditionally, multinational firms used United States GAAP specialists to conform financial statements to comply with SOX regulations. ${ }^{207}$ Section 404 requires reports filed by companies under the provisions of SOX must conform to GAAP standards. ${ }^{208}$ Corporations are required to demonstrate thatthey have the appropriate experience ; they cannot rely on external sources to "fix" financial statements to conform to GAAP standards. "209 "The independent auditor's independence is impaired if they are considered to be a part of the company's system internal control."210

This provision can be especially burdensome for foreign issuers and multinational corporations whose principal place of business is outside of the United States. ${ }^{211}$ In many jurisdictions outside of the United States, there are a limited amount of audit partners that possess the requisite knowledge of GAAP standards. ${ }^{212}$ In addition, most large multinational

\footnotetext{
${ }^{202}$ DeloitTe \& TOUCHE, supra note 198, at 4.

203 Id. at 5 .

${ }^{204} \mathrm{Id}$.

${ }^{205} I d$. at 3. GAAP are the common set of "accounting principles, standards and procedures that companies use to compile their financial statements." Generally Accepted Accounting Principles, http://www.investopedia.com/terms/g/gaap.asp (last visited Oct. 7, 2005).

${ }^{206}$ PRACTICAL GUIDE, supra note 17, at 132.

${ }^{207}$ DELOITTE \& TOUCHE, supra note 198 , at 3.

${ }^{208} \mathrm{Id}$.

${ }^{209} \mathrm{Id}$.

${ }^{210}$ Id. at 5.

${ }^{211}$ Mélanie Lambelet, The Extraterritorial Effects of the Sarbanes-Oxley Act of 2002, MÉMOIRE MBL, Oct. 2003, at 28, available at http://www.unige.ch/droit/mbl/upload/pdf/MEMOIRE_Melanie_Lambelet.pdf.

${ }^{212}$ Letter from Deloitte and Touche LLP to Jonathan Katz, Secretary, SEC (Jan. 10, 2003) (on file with the SEC), available at http://www.sec.gov/rules/proposed/s74902/deloitte1.htm.
} 
corporations require "line" partners to complete their audits. ${ }^{213}$ Developing "line" partners, who can maintain the level of experience needed by the corporation, is "costly, difficult, and time consuming." 214 Audit firms are also severely limited in their ability to fill critical partner roles for these clients. ${ }^{215}$ This could decrease the quality of work done by these firms and defeat the purpose for implementing this provision. ${ }^{216}$

Section 406 requires corporations to adopt a code of ethics or to state why they have not adopted a code of ethics. ${ }^{217}$ This provision applies to domestic firms and foreign private issuers. $^{218}$ The distinction between domestic firms and foreign private issuers under this section is thatforeign $\mathrm{p}$ rivate issuers do not have to provide a current report of a change in the issuer's code of ethics. $^{219}$ A foreign private issuer only has to disclose changes once a year in its annual report. $^{220}$

The Organization for Economic Co-Operation and Development (OECD) has provisions for a code of ethics to build public trust. ${ }^{221}$ It is not mandated thatcorporations adopt of code of ethics, but the code will aid the process of corporate governance and encourage the reporting of

${ }^{213} I d$.

${ }^{214} I d$.

${ }^{215} I d$.

${ }^{216} \mathrm{Id}$.

${ }^{217}$ PRACTICAL GUIDE, supra note 17, at 427.

${ }^{218}$ Id.

${ }^{219}$ Holme Roberts \& Owen, Final Rules: Code of Ethics, HRO ALERT, Feb. 7, 2003, 1, 2, available at http://www.hro.com/pubs/FRethics.pdf.

${ }^{220} \mathrm{Id}$.

${ }^{221}$ OECD, Prinicples of Corporate Governance (2004), available at http://www.oecd.org/dataoecd/47/50/4347646.pdf. The OECD groups:

30 member countries sharing a commitment to democratic government and the market economy. With active relationships with some 70 other countries, NGOs and civil society, it has a global reach. Best known for its publications and its statistics, its work covers economic and social issues from macroeconomics, to trade, education, development and science and innovation.

OECD, http://www.oecd.org/about/0,2337,en_2649_201185_1_1_1_1_1,00.html. 
unethical behavior. $^{222}$ Almost all of the countries in the OECD also use training programs to raise awareness of ethical issues. ${ }^{223}$

Section 409 requires "real-time" disclosure of a number of key occurrences and transactions, which may be of importance to investors. ${ }^{224}$ This presents a complication for foreign issuers and multinational corporations. ${ }^{225}$ Time zone differences could affect the disclosure by corporations headquartered outside of the United States. ${ }^{226}$ The requirement that all disclosed documents must be in English presents a unique problem for foreign issuers whose first language is not English. ${ }^{227}$ This provision could lead to increased costs for document translation and other factors arising from the language barrier. ${ }^{228}$

Section 806 prohibits employers from taking adverse action against an employee when they take "lawful actions to disclose information or otherwise assist criminal investigators, federal regulators, Congress, supervisors . . . or parties in a judicial proceeding in detecting and stopping fraud."229 There are many implications for multnational corporations under this section. The differences of corporate culture in America and other countries can lead to conflicts

\footnotetext{
${ }^{222}$ OECD, Prinicples of Corporate Governance (2004), available at http://www.oecd.org/dataoecd/47/50/4347646.pdf.

${ }^{223}$ OECD Public Management Policy Brief, Building Public Trust: Ethics Measures in OECD Countries, Sept. 2007, available at www.oecd.org/dataoecd/60/43/1899427.pdf. The OECD is comprised of the following countries: Republic of Austria, the Kingdom of Belgium, Canada, the Kingdom of Denmark, the French Republic, the Federal Republic of Germany, the Kingdom of Greece, the Republic of Iceland, Ireland, the Italian Republic, the Grand Duchy of Luxembourg, the Kingdom of the Netherlands, the Kingdom of Norway, the Portuguese Republic, Spain, the Kingdom of Sweden, the Swiss Confederation, the Turkish Republic, the United Kingdom of Great Britain and Northern Ireland, and the United States of America.

Convention on the Organisation for Economic Co-operation and Development, Dec. 14, 1960, available at http://www.oecd.org/document/7/0,2340,en_2649_201185_1915847_1_1_1_1,00.html.

${ }^{224}$ PRACTICAL GUIDE, supra note 17 , at 436 .

${ }^{225}$ Kelley, supra note 167, at 25.

${ }^{226} I d$.

${ }^{227} \mathrm{Id}$.

${ }^{228} \mathrm{Id}$.

${ }^{229}$ PRACTICAL GuIDE, supra note 17 , at 811.
} 
in reporting misconduct. ${ }^{230}$ There are many countries where whistleblowing is seen as a return to the government intruding on the business practices of corporations. ${ }^{231}$ In countries such as Italy and France, it sparks memories of experiences with collaborators during World War II. ${ }^{232}$ Even with this section of SOX, many employees outside of the United States will be hesitant to report violations. $^{233}$

The whistleblowing provision of SOX conflicts with the EU Data Protection Law. ${ }^{234}$ In complying with SOX, many corporations have established telephone hotlines or even a complaint system where employees can make anonymous complaints on the internet. ${ }^{235}$ The submissions may contain information about fellow employees and management. ${ }^{236}$ The EU data protection laws are very strict in the circumstances for the collection and disclosure of personal information. $^{237}$

Article 26, Section 2 of the 1995 European Parliament Directive on the protection of individuals with regard to the processing of data, states:

Without prejudice to paragraph 1, a Member State may authorize a transfer or a set of transfers of personal data to a third country which does not ensure an adequate level of protection within the meaning of Article 25 (2), where the controller adduces adequate safeguards with respect to the protection of the privacy and fundamental rights and freedoms of individuals and as regards the exercise of the corresponding rights; such safeguards may in particular result from appropriate contractual clauses. $^{238}$

\footnotetext{
${ }^{230}$ Curtis C. Verschoor, Is This the Age of Whistleblowers?, STRATEGIC Fin., Jan. 2005, at 17, 18, available at http://www.imanet.org/ima/docs/2900/2849.pdf.

${ }^{231} I d$. at 18 .

${ }^{232} I d$.

${ }^{233} \mathrm{Id}$.

${ }^{234}$ Hunton \& Williams, Conflict between Sarbanes-Oxley Whistleblower Provisions and EU Data Protection Law, CLIENT ALERT, June 2005, at 1, 1.

${ }^{235} I d$.

${ }^{236} \mathrm{Id}$.

${ }^{237} \mathrm{Id}$.

${ }^{238}$ Council Directive 1995/46, 1995 O.J. (L 281) 46 (EC), available at http://europa.eu.int/smartapi/cgi/sga_doc?smartapi!celexapi!prod!CELEXnumdoc\&lg=EN\&numdoc=31995L0046\& model=guichett.
} 
This article lays out the protection for individuals in the EU and the restrictions of processing information and sending it to non-EU countries. ${ }^{239}$ The directive also requires that" the processing of personal information must not adversely affect the personal freedom of individuals, and imposes consent and disclosure requirements., 240

The SOX whistleblowing provision conflicts with laws outside of the United States and these conflicts can be seen in a German labor court decision and a decision by the French National Commission for Data Protection and the Liberties. ${ }^{241}$ The French decision was based on the French data protection law. ${ }^{242}$ The decision prohibited two companies, McDonald's and CEAC Exide Technology, from setting up anonymous reporting systems. ${ }^{243}$ The reporting systems, "hotlines", were deemed to be illegal in France. ${ }^{244}$ The Commission Nationale de L'informatique et des Libertes (CNIL) found there to be a lack of transparency due to the fact a whistleblower's allegations against another employee may not be accessible to the target of the allegations. ${ }^{245}$ The commission also found the hotlines to be a breach of ethics and unfair to employees accused, because they would not have the means to defend themselves or oppose proceedings which may involve criminal sanctions. ${ }^{246}$ This result creates a legal bind for companies: how can you implement SOX when it conflicts with local laws of countries where

\footnotetext{
${ }^{239}$ Hunton \& Williams, supra note 234, at 2.

${ }^{240} I d$.

${ }^{241}$ Mark E. Schreiber \& Jeffrey M. Held, Anonymous Sarbanes Oxley Hotlines in the E.U.: Practical Compliance Guidance for Global Companies, WORLD DATA PROTECTION REPORT, Aug. 2005, available at http://www.theworldlawgroup.com/db30/cgi-bin/pubs/SOX\%20Hotlines.doc. The English translation of the French case may be found here. www.theworldgroup.com/newsletter/details.asp?ID=1246367122005. The English translation for the German case may be found at this website. www.theworldgroup.com/newsletter/details.asp?ID=745557282005.

${ }^{242}$ Commission Nationale de L'informatique et des Libertes, Act n ${ }^{\circ} 78-17$ of 6 January 1978 on Data Processing, Data Files and Individual Liberties, available at http://www.cnil.fr/fileadmin/documents/uk/78-17VA.pdf.

${ }^{243}$ Schreiber \& Held, supra note 241.

${ }^{244} \mathrm{Id}$.

${ }^{245} \mathrm{Id}$.

${ }^{246} I d$.
} 
business is being done $?^{247}$ Christopher Kuner, an attorney with the Hunton \& Williams law firm based in Brussels, made this conflict clear when he stated companies are being told "I either have to chop off my left hand or my right hand.",248

The German case was a decision handed down by the Fifth Division of the Wuppertal Labor Court on June 15, 2005. ${ }^{249}$ The court held Wal-Mart had to discontinue use of an employee complaint hotline for German employees until an agreement could be reached. ${ }^{250}$ The court also held provisions of the code of conduct implemented by Wal-Mart were invalid under German law. ${ }^{251}$ The court found Wal-Mart did not did not request consent of the works council of Wal-Mart. ${ }^{252}$ The court also founded their decision on German data protection laws. ${ }^{253}$ German data protection law "does not recognise an intra-group privilege for the transfer of data."254 "Where the data is ultimately transferred to the United States, either the EC Commission standard contractual clauses have to be implemented or the U.S. company has to certify according to the Safe Harbor regulations." 255

\footnotetext{
${ }^{247}$ David Reilly \& Sarah Nassauer, Tip-line bind: Follow the law in U.S. or EU?, WALL ST. J., Sept. 6, 2005, available at http://www.post-gazette.com/pg/05249/566468.stm. stipulates "works councils must be established in all companies that have five or more regular employees." Id. The function of the works council under this law is "to protect the "collective labor rights' of the employees of the company." Id. The Works Council Directive created a works council for Wal-Mart in the European Union. 2002 O.J. (L 80) 29. The purpose of the Works Council Directive is "to establish a general framework setting out minimum requirements for the right to information and consultation of employees in undertakings or establishments within the Community." 2002 O.J. (L 80) 29, 31.

${ }^{253}$ Schreiber \& Held, supra note 241.

${ }^{254} \mathrm{Id}$.

${ }^{255}$ Id. Use of the Contractual Clauses "should be considered whenever there is an intention to transfer personal data from within the EC to a country outside the European Economic Area that has not been recognized as providing adequate protection to personal data." Goodwin Proctor, European Commission Approves Standard Contractual Clauses for Personal Data Transfers, IP / TECH ADVISOR, July 2001, available at http://www.goodwinprocter.com/publications/IPA_personaldatatransfers_8_01.pdf. "Certifying to the safe harbor will assure that EU organizations know that your company provides 'adequate' privacy protection, as defined by the Directive.” U.S. Dept. of Com., Safe Harbor Overview, http://www.export.gov/safeharbor/sh_overview.html (last visited Nov. 6, 2005).
} 
Section 906 imposes criminal sanctions on CEOs and CFOs who file misleading or false financial statements. ${ }^{256}$ This provision seems to conflict or overlap with regulations imposed by the International Organization for Standardization (ISO) ${ }^{257}$ Under the ISO provisions, dishonest reports and fraudulent quality systems are criminalized. ${ }^{258}$ With this level of regulation, it might be viewed as creating too much of a burden of suspicion on top management and seems to put a magnifying glass to companies who are registered under the ISO and are also subject to SOX regulations. $^{259}$

\section{ENFORCEMENT ISSUES OF SOX}

SOX affects all companies listed on any stock exchange in the United States. ${ }^{260}$ The Act directly affects "management, audit committees, public company auditors, attorneys, and brokerage firms." ${ }^{261}$ SOX affects companies operating domestically in the United States and also multinational companies, including foreign companies cross-listing on the United States stock exchanges. ${ }^{262}$ Harvey L. Pitt, Chairman of the SEC, has spoken on the issue of the extraterritoriality. ${ }^{263} \mathrm{He}$ stated “'We are aware of the fact that [many of the Act's] requirements . .. can conflict with internal corporate structures and legal requirements in home

\footnotetext{
${ }^{256}$ PRACTICAL GUIDE, supra note 17 , at 904.

${ }^{257}$ William A. Stimson, Sarbanes-Oxley and ISO 9000, QUALITY PROGRESS, March 2005, at 24, 28, available at http://sqp.asq.org/pub/qualityprogress/past/0305/qp0305stimson.pdf. The ISO only affects companies who are registered under the ISO. Id. A list of countries following the ISO standards can be found here. International Organization for Standardization, http://www.iso.org/iso/en/aboutiso/isomembers/MemberList.MemberSummary?MEMBERCODE=10 (last visited Nov. 6, 2005).

${ }^{258}$ Stimson, supra note 257, at 28. The provisions can be found in the ISO 9001, which is a set of managed and applied procedures. $I d$, at 25 . The certain provisions criminalizing dishonest reports and fraudulent quality systems are clauses 4.2.3, 4.2.4, and 8.0. Id, at 28. An English translation of the ISO $9001 \mathrm{can}$ be found here. ISO 9001, http://praxiom.com/iso-9001.htm (last visited Nov. 6, 2005).

${ }^{259}$ Id. at 29.

${ }^{260}$ Raising the Rent, supra note 4, at 28.

${ }^{261}$ PRACTICAL GUIDE, supra note 17 , at xxi. SOX not only affects public companies, but also affects private companies indirectly. Id. Once private companies see SOX raising the public expectations for good corporate governance, they will also have to conform or lose business. Id. Nonprofit organizations and accountants who do not audit public companies will also feel the indirect effects of SOX. Id at xxii.

${ }^{262}$ Raising the Rent, supra note 4 , at 3.

${ }^{263}$ Ackerly, supra note 168.
} 
jurisdictions.",264 He urged any effected party to "'let us know when our proposals conflict with local law or local stock exchange requirements. . . [W]e do promise to listen, ... and do our best to harmonize the application of our rules with foreign sovereign requirements.",265

\section{A. Extraterritoriality Problems of SOX}

The United States assertion of SOX in the global forum has created controversy all over the world. ${ }^{266}$ SOX was applauded domesticallybut was greatly criticized interna tionally. ${ }^{267}$ SOX was criticized for "being made applicable to all foreign issuers listed on a U.S. exchange, even though some of the behavior the Act targeted was either a non-issue in foreign countries or was already efficiently regulated.",268

\section{Statutory Enforcement Power under SOX}

The statutory enforcement language of SOX can be found in Section Three of the Act. ${ }^{269}$ Section Three is entitled "Commission Rules and Enforcement." ${ }^{270}$ It covers both regulatory actions of the commission and enforcement powers. ${ }^{271}$ The term "commission" means the SEC. ${ }^{272}$ Under this provision, the SEC "shall promulgate such rules and regulations, as may be necessary or appropriate in the public interest or for the protection of investors, and in furtherance of this Act." 273

\footnotetext{
${ }^{264}$ Ackerly, supra note 168.

${ }^{265} \mathrm{Id}$.

${ }^{266}$ Vancea, supra note 154 , at 839.

${ }^{267}$ Cheryl Jerome Moore, Current Issues Regarding Corporate Governance and Multinational Corporations, http://library.findlaw.com/2004/Oct/27/133621.html (last visited Nov. 6, 2005).

${ }^{268}$ Vancea, supra note 154 , at 839.

${ }^{269}$ The Act, supra note 27 , at $\$ 3$.

${ }^{270} \mathrm{Id}$.

${ }^{271}$ PRACTICAL GUIDE, supra note 17 , at 3004.

${ }^{272} I d$. at 3003 . This definition can be found in the definitions section of SOX at Section 2. Id. at 3002.

${ }^{273}$ Id. at 3004 .
} 
The enforcement provision can be found in Section Three of SOX. ${ }^{274}$ The enforcement

provision states,

A violation by any person of this Act, any rule or regulation of the Commission issued under this Act, or any rule of the Board shall be treated for all purposes in the same manner as a violation of the Securities Exchange Act of 1934 (15 U.S.C 78a et seq.) or the rules and regulations issued thereunder, consistent with the provisions of this Act, and any such person shall be subject to the same penalties, and to the same extent, as for a violation of that Act or such rules or regulations. ${ }^{275}$

This provides a broad grant of jurisdictional authority for the SEC and Department of Justice to

impose criminal and civil sanctions under the requirements contained in SOX. ${ }^{276}$

\section{United States Assertion of Exterritorial Jurisdiction}

The assertion of extraterritorial jurisdiction by the United States has been criticized by

the international community. ${ }^{277}$ Extraterritorial jurisdiction is defined as:

... the operation of a U.S. law so as to encompass activities where (1) the conduct at issue occurs within the U.S., but its effects take place abroad; (2) the conduct occurs abroad, but its effects take place in the U.S.; or (3) both the conduct and its effect occur abroad. ${ }^{278}$

\footnotetext{
${ }^{274}$ PRACTICAL GuIDE, supra note 17, at 3004.

${ }^{275}$ Id. The Securities Exchange Act of 1934 regulates securities exchanges and corporate responsibility. 15 U.S.C.A $\S 78 \mathrm{a}$ (West, Westlaw through Sept. 2005 amendments).

${ }^{276}$ Stephen M. Kohn, The Sarbanes-Oxley Act ("SOX”): Legal Protections for Corporate Whistleblowers, http://www.whistleblowers.org/html/sarbanes-oxley.htm (last visited Nov. 6, 2005).

${ }^{277}$ Vancea, supra note 154 , at 833.

${ }^{278}$ Id. The principles of extraterritorial jurisdiction can be found in $\$ 402$ of the Restatement (Third) of the Foreign Relations Law of the United States. RESTATEMENT (THIRD) OF THE FOREIGN RELATIONS LAW OF THE UNITED STATES § 402 (1987) [HEREINAFTER RESTATEMENT]. See also id. at §403 (1987) ( Factors assessing the reasonableness of asserting jurisdiction to prescribe over a matter are:
}

(1) Even when one of the bases for jurisdiction under $\S 402$ is present, a state may not exercise jurisdiction to prescribe law with respect to a person or activity having connections with another state when the exercise of such jurisdiction is unreasonable.

(2) Whether exercise of jurisdiction over a person or activity is unreasonable is determined by evaluating all relevant factors, including, where appropriate:

(a) the link of the activity to the territory of the regulating state, i.e., the extent to which the activity takes place within the territory, or has substantial, direct, and foreseeable effect upon or in the territory;

(b) the connections, such as nationality, residence, or economic activity, between the regulating state and the person principally responsible for the activity to be regulated, or between that state and those whom the regulation is designed to protect;

(c) the character of the activity to be regulated, the importance of regulation to the regulating state, the extent to which other states regulate such activities, and the degree to which the desirability of such regulation is generally accepted.

(d) the existence of justified expectations that might be protected or hurt by the regulation;

(e) the importance of the regulation to the international political, legal, or economic system; 
SOX is concerned with the conduct that takes place in the United States, but the effects are felt abroad. $^{279}$ The Restatement (Third) of the Foreign Relations Law of the United States describes the link between territoriality and nationality:

International law recognizes links of territoriality, Subsection (1), and nationality, Subsection (2), as generally justifying the exercise of jurisdiction to prescribe. But these links are not sufficient in all cases: not all activities within a state's territory, nor all activities of a state's nationals, may reasonably be subjected to its legislation. ${ }^{280}$

However, this is a rule stated in a Restatement of the law and does not bind any court until it adopts the rule. ${ }^{281}$

Jurisdiction is the "power of a sovereign to affect the rights of persons, whether by legislation, by executive decree, or by the judgment of a court."282 This definition lays out the principle that a "State has the right to exercise jurisdiction within the limits of its sovereignty, but is not entitled to encroach upon the sovereignty of other States."283 International law imposes "limits on the ability of states to encroach on the sovereignty of other states by delineating the acceptable bases for asserting jurisdiction." 284

There are two types of limitations used by the United States courts in determining the extent of jurisdiction. ${ }^{285}$ The limitations applied by the courts are the subject mattertest and system;

(f) the extent to which the regulation is consistent with the traditions of the international

(g) the extent to which another state may have an interest in regulating the activity; and

(h) the likelihood of conflict with regulation by another state).

${ }^{279}$ Vancea, supra note 154, at 835.

${ }^{280}$ RESTATEMENT, supra note 278 , at $\$ 402$.

${ }^{281}$ Shirley, supra note 6 , at 521.

${ }^{282}$ Joseph H. Beale, The Jurisdiction of a Sovereign State, 36 HARV. L. REV. 241, 241 (1923).

${ }^{283}$ James D. Cox, Regulatory Duopoly in U.S. Securities Markets, 99 COLUM. L. REv. 1200, 1240 n.130 (1999).

${ }^{284}$ Vancea, supra note 154 , at 846.

${ }^{285} I d$. at 848 . 
prescriptive test to determine jurisdiction. ${ }^{286}$ These limitations are in addition to the limitations set by international law. ${ }^{287}$

The subject matter test for United States extraterritoriality is based on two presumptions. ${ }^{288}$ The first presumption is that acts of Congress are not to be construed in violation of international law. ${ }^{289}$ This presumption is known as the Charming Betsy presumption. ${ }^{290}$ The presumption recognizes the potential for international conflict created by violations of international law and is used to determine vague congressional intent. ${ }^{291}$ The second presumption is imposed under a canon of construction stating "legislation of Congress, unless a contrary intent appears, is meant to apply only within the territorial jurisdiction of the United States. ${ }^{292}$ This presumption is known as the Foley Bros. presumption. ${ }^{293}$ To discern Congressional intent the Supreme Court relied upon three factors: (1) the absence of an expressed intent that the statute apply to foreign companies; ${ }^{294}(2)$ the legislative history of the statute $^{295}$ (3) administrative decisions. ${ }^{296}$

\section{Extraterritoriality of Securities Regulation before SOX}

\footnotetext{
${ }^{286}$ Vancea, supra note 154 , at 848.

${ }^{287}$ Id. The Supreme Court laid out the appropriate sources of international law when it stated international law "may be ascertained by consulting the works of jurists, writing professedly on public law; or by the general usage and practice of nations; or by judicial decisions recognizing and enforcing that law." Filartiga v. Pena-Irala, 630 F.2d 876, 880 (quoting United States v. Smith, 18 U.S. (5 Wheat.) 153, 160-61 (1820)).

${ }^{288}$ Vancea, supra note 154 , at 848.

${ }^{289}$ Murray v. Schooner Charmin Betsy, 6 U.S. 64, 118 (1804). "[A]n act of Congress ought never to be construed to violate the law of nations if any other possible construction remains." Id. This case was a controversy over a vessel sold in a Danish island and whether it was liable to seizure under the non-intercourse law of February 27, 1800. Id at 65.

${ }^{290}$ Vancea, supra note 154 , at 849.

${ }^{291}$ Id

${ }^{292}$ Foley Brothers v. Filardo, 336 U.S. 281,285 (1949). This case dealt with a controversy concerning overtime wages due to an employee under the Federal Eight Hour Law. Id at 281. See also American Banana Company v. United Fruit Company, 213 U.S. 347 (1909) (holding that when a statute is silent on jurisdiction, it should be construed to only apply to conduct occurring in the territory of the United States).

${ }^{293}$ Vancea, supra note 154 , at 849.

${ }^{294}$ Foley Brothers, 336 U.S. at 285.

${ }^{295} \mathrm{Id}$ at 286.

${ }^{296}$ Id at 288.
} 
The extraterritoriality of securities regulations is not a drastic or new idea; corporations outside of the United States have been subjected to United States securities regulations for quite some time. ${ }^{297}$ The first case examining the scope of Securities regulation outside of the United States was in Schoenbaum v. Firstbrook, a case that was filed in $1968 .{ }^{298}$ Schoenbaum was a controversy over whether the Securities Exchange Act of 1934 applied to a Canadian oil company, listed on an American stock exchange that was engaging in insider trading. ${ }^{299}$ The district court granted summary judgment to defendants on the grounds that the complaint failed to state a claim under section 10(b) of the Securities Exchange Act of $19344^{300}$ The Court of Appeals reversed in part and affirmed in part. The Court of Appeals stated:

. . plaintiff stockholder's allegations that majority stockholder, knowing true value of corporation's stock, used its control over corporation to acquire 500,000 shares at a vastly inadequate price shortly before public announcement of corporation's oil discovery required that plaintiff be permitted through discovery to develop evidence to counter defense affidavits, but that where it appeared that negotiations for purchase of treasury stock by other defendant were at arm's length and that purchaser, and those whom it represented, were unable to bring any pressure on corporation to sell its stock at price below its true value, purchaser was entitled to dismissal of action against it. $^{301}$

The court reversed on the issue of extraterritoriality, but decided that the insiders had not engaged in illegal insider trading regardless of their decision on the extraterritoriality argument. $^{302}$ This decision found the Securities Exchange Act of 1934 applied extraterritorially. ${ }^{303}$ The case also created the "effects" test under federal securities laws. ${ }^{304}$

\footnotetext{
${ }^{297}$ Shirley, supra note 6, at 515.

${ }^{298}$ Schoenbaum, 405 F.2d at 215.

${ }^{299}$ Siegel, supra note 9.

${ }^{300}$ Schoenbaum, 405 F.2d at 215. Section 10(b) of the Securities Exchange Act of 1934 deals with manipulative and deceptive devices. 15 U.S.C.A. $\S 78$ j (West 2000). This provision is used to protect the public interest and also the investors of corporations. Id.

${ }^{301}$ Schoenbaum, 405 F.2d at 215.

${ }^{302}$ Siegel, supra note 9.

${ }^{303}$ Vancea, supra note 154, at 850. See also Kohn v. American Metal Climax Inc.,489 F.2d 262 (New York based insiders of a Zambian firm, who listed on and American stock exchange, had violated disclosure laws; court found jurisdiction); Derensis v. Coopers \& Lybrand Chartered Accountants, 930 F.Supp. 1003 (Canadian company listed on an American stock exchange was charged with securities fraud; court found jurisdiction); Landry v. Price Waterhouse Chartered Accountants, 715 F. Supp. 98 (Canadian company listed on an American stock exchange was charged with financial fraud; court found jurisdiction); In Re Baan Company Securities Litigation, 284 F.Supp.2d 62
} 


\section{International Comity Considerations}

Comity is a term used in international law when dealing with relations between the United States and other nations. ${ }^{305}$ It is described as an "informal principle that nations will extend certain courtesies to other nations, particularly by recognizing the validity and effect of their executive, legislative, and judicial acts."306 This issue is most frequently raised by the courts, which should not "act in a way that demeans the jurisdiction, laws or judicial decisions of another country."307 The courts have adopted multiple balancing tests to address questions of comity and extraterritorality desiring to avoid undue intrusion into the business and affairs of other countries. $^{308}$

An important case in setting out the United States view of comity is the Supreme Court decision of Hartford Fire Insurance Company v. California. ${ }^{309}$ This case involved the

(Dutch company listed on United States stock exchange sued for making financial misstatements; court found jurisdiction).

${ }^{304}$ United States v. Aluminum Company of America, 148 F.2d 416, 444 (2d Cir. 1945) (Judge Learned Hand adopted the "effects" test; the court held the Sherman Act applied to foreign firms if their conduct affected the United States). For the "effects" test you must look "whether the transaction or conduct has, or can reasonably be expected to have, a substantial effect on a securities market in the United States for securities of the same issuer or on holdings in such securities by United States nationals or residents." RESTATEMENT, supra note $278, \S 416$.

${ }^{305}$ Comity, http://en.wikipedia.org/wiki/Comity (last visited Oct. 14, 2005).

${ }^{306} \mathrm{Id}$.

${ }^{307}$ Id. But see Societe Nationale Industrielle Aerospatiale v. United States Dist. Court 482 U.S. 522 , 553 (Blackmun J., concurring in part and dissenting in part) (arguing that interest balancing is more appropriately considered by the Executive and Congress because judges lack experience with foreign legal systems, misapprehend foreign procedural rules, inaccurately assess foreign responses to particular acts, and are likely to exhibit a pro-forum basis), Vancea, supra note 237, n. 136.

${ }^{308}$ Patton Boggs, LLP, Current Issues Regarding Corporate Governance and Multinational Corporations, http://library.findlaw.com/2004/Oct/27/133621.html (last visited Nov. 6, 2005). When dealing with balancing the interests of multiple countries, you must ask the question "Does the need for a U.S. rule of law, in this instance, outweigh the likelihood of conflict with foreign laws and practices?" Nanda, Ved P. et al., 1 Litigation of International Disputes in U.S. Courts $\$ 5: 1$ (2004).

${ }^{309}$ Hartford Fire Insurance Co. v. California, 509 U.S. 764 (1993). Compare SEC v. Banca Della Svizzera Italiana, 92 F.R.D. 111, 117-18. (S.D.N.Y 1981) (expressing concern that "secret foreign financial institutions ... have allowed Americans and others to avoid the law and regulations concerning securities and exchanges") with United States v. Nippon Paper Indus. Co., 109 F.3d 1, 8 (1st Cir. 1997) (refusing to dismiss criminal antitrust charges on comity grounds since to do so "would create perverse incentives for those who would use nefarious means to influence markets in the United States, rewarding them for erecting as many territorial firewalls as possible between cause and effect"). 
jurisdiction of the Sherman Antitrust Act over foreign reinsurers. ${ }^{310}$ The Supreme Court held that the Sherman Act did have extraterritorial jurisdiction over foreign reinsurers under principles of international comity. ${ }^{311}$ The main issue the court struggled with was whether the provisions of the Sherman Act were in direct conflict with foreign law. ${ }^{312}$ Reinsurers from London argued that the Sherman Act conflicted with British Law. ${ }^{313}$ It was well settled law before this case was decided that the Sherman Act applied to conduct by foreign parties that produced a substantial effect in the United States. ${ }^{314}$ The court found that there was no conflict with British law. ${ }^{315}$ The court also found that"where a person subject to regulation by two states can comply with the laws of both.,316

\section{Extraterritoriality of SOX}

SOX regulations apply to all companies listed on any United States exchange regardless of whether it is a domestic or foreign company. ${ }^{317}$ In some instances, however, SOX makes it impossible to comply with laws in countries outside the United States. ${ }^{318}$ A good example is Australia; under Australian corporate law, shareholders select the auditor instead of a committee like required under SOX. ${ }^{319}$ This is a situation where the regulation under SOX directly conflicts

\footnotetext{
${ }^{310}$ Hartford Fire Insurance Co., 509 U.S. at 764. The Sherman Antitrust Act was passed in 1980 to disband existing monopolies and not let any more arise in their place. 15 U.S.C. $\S \S 1-7$.

${ }^{311}$ Hartford Fire Insurance Co., 509 U.S. at 764.

${ }^{312} \mathrm{Id}$. at 798.

${ }^{313} \mathrm{Id}$. at 798 .

${ }^{314}$ Id at 795. See also Matsushita Elec. Industrial Co. v. Zenith Radio Corp., 475 U.S. 574, 582, n. 6 (1986) (American television manufacturers could not recover antitrust damages against Japanese television manufacturers for any conspiracy by the Japanese manufacturers since such conduct could not injure the American manufacturers who stood to gain from any such conspiracy); United States v. Aluminum Co. of America, 148 F.2d 416 (2d Cir. 1945) (Judge Learned Hand adopted the "effects" test; the court held the Sherman Act applied to foreign firms if their conduct affected the United States); RESTATEMENT $\$ 415$ (Any agreement in restraint of United States trade that is made in the United States, and any conduct or agreement in restraint of such trade that is carried out in significant measure in the United States, are subject to the jurisdiction to prescribe of the United States, regardless of the nationality or place of business of the parties to the agreement or of the participants in the conduct).

${ }^{315}$ Hartford Fire Insurance Co., 509 U.S. at 798.

${ }^{316} I d$. at 798 (citing RESTATEMENT § 403).

${ }^{317}$ Information Guide, supra note 15.

${ }^{318}$ Patton Boggs, LLP, supra note 308.

${ }^{319} \mathrm{Id}$.
} 
with the law of a host country, and falls specifically under the comity concerns raised in Hartford Fire Insurance Co.. ${ }^{320}$

SOX specifically regulates all firms listing on a United States exchange regardless of whether they are a domestic or foreign company. ${ }^{321}$ SOX regulates these companies by using specific language out of the Act. Extraterritoriality can be found under the language of SOX, by using the specific language of enforcement provisions, which make no distinction between domestic and foreign firms. ${ }^{322}$ This can be analogized to the Supreme Court's holding in Hartford Fire Insurance Co.. ${ }^{323}$ The court talks about a type of jurisdiction relevant to the extraterritorial reach of a statute known as "legislative jurisdiction" or "jurisdiction to prescribe". ${ }^{324}$ When deciphering the jurisdiction issue, look to the intent of the legislature for guidance. ${ }^{325}$ The courts have consistently held that the legislation of Congress, unless a contrary intent appears, is meant to only apply in the territory of the United States. ${ }^{326}$ The enforcement language under $\mathrm{SOX}^{327}$ would seem to indicate that Congress meant for the Act to apply to all companies listed on a United States Exchange, both foreign and domestic. ${ }^{328}$

To discern the Congressional intent behind SOX, look to the legislative history behind the Act. ${ }^{329}$ Members of Congress were very reluctant in imposing SOX regulations on countries whose corporate responsibility frameworks were adequate or superior to the corporate

\footnotetext{
${ }^{320}$ Hartford Fire Insurance Co., 509 U.S. at 798. If the British law would have been in direct conflict with the Sherman Act, then a comity issue would have arisen. $I d$.

${ }^{321}$ The Act, supra note 27 , at $\$ 3$.

322 The Act, supra note 27 , at $\$ 3$.

${ }^{323}$ Hartford Fire Insurance Co., 509 U.S. at 798.

${ }^{324}$ Id. (citing E.E.O.C. v. Arabian American Oil Co., 499 U.S. at 253). This case held that Title VII of the Civil Rights Act does not apply extraterritorially. E.E.O.C., 499 U.S. at 244.

${ }^{325}$ Hartford Fire Insurance Co., 509 U.S. at 798.

${ }^{326}$ Id at 798 (quoting E.E.O.C. v. Arabian American Oil Co., 499 U.S. at 248).

327 The Act, supra note 27 , at $\$ 3$.

${ }^{328}$ Raising the Rent, supra note 4 , at 3.

${ }^{329}$ Foley Brothers, 336 U.S. at 286.
} 
responsibility framework of the United States. ${ }^{330}$ Senator Enzi, during a discussion on the Senate floor, stated:

While foreign issuers can be listed and traded in the U.S. if they agree to conform to GAAP and New York Stock Exchange rules, the SEC historically has permitted the home country of the issuer to implement corporate governance standards. Foreign issuers are not part of the current problems being seen in the U.S. capital markets, and I do not believe it was the intent of the conferees to export U.S. standards disregarding the sovereignty of other countries as well as their regulators. ${ }^{331}$

Senator Enzi's opinion shows that at least some of the lawmakers behind the passage of

SOX desired the legislation to only regulate companies in the United States, because

foreign companies were not part of the scandals leading up to the passage of this bill. ${ }^{332}$

\section{SUCCESS OF SOX}

The question asked by companies both in the United States and abroad is whether SOX

has had a positive effect on securities markets around the world or if it has imposed too great of a regulation. When SOX was implemented in 2002, an international outcry from many

multinational corporations and foreign firms rang out claiming that SOX was ineffective and that Congress "rushed" the legislation. ${ }^{333}$ Multinational firms all across the world have clamored for exemptions from the regulations imposed by SOX ${ }^{334}$ These firms requested exemptions from certain provisions of SOX such as prohibitions on foreign loans ${ }^{335}$ and forfeitures by certain officers of compensation and securities-related profits. ${ }^{336}$ Multinational corporations have formed the Reciprocity in International Accounting Coalition to "push for changes that affect

\footnotetext{
${ }^{330} 148$ Cong. Rec. S 7350, 7356 (2002).

${ }^{331} \mathrm{Id}$. at 7356 (2002). Mike Enzi is a senator from Wyoming. Senator Mike Enzi, http://enzi.senate.gov/ (last visited Nov. 9, 2005).

332148 Cong. Rec. S at 7356 (2002).

${ }^{333}$ Lucci, supra note 151 , at 219.

${ }^{334}$ Id. at 219 (citing Fiona Buffini, Multinationals Seek Exemption from Act, AUSTL. FIN. REV., Sept. 2, 2002, at 16).

335 The Act, supra note 27 , at $\S 402$.

${ }^{336} I d$. at $\$ 304$. The multinational firms are part of the Organization for International Investment (OFII). Letter from OFII, to Jonathan G. Katz, Secretary, Sec. Exch., Comm'n (August 19, 2002) (on file with the Sec. Exch. Comm'n), available at http://www.ofii.org/SEC_Letter_081902.pdf. OFII is the "leading business association in the United States representing the interests of U.S. subsidiaries of nearly 100 international companies.” Id.
} 
international companies and their corporate officers."337 A concern for the United States

securities market is whether the regulation of SOX will have an effect on companies cross-listing

on a United States exchange and also the influence SOXhas on foreign and multinational firms

when creating models of corporate governance regimes in their respective countries of

domicile. $^{338}$

\section{A. The Decision to Cross-List}

Cross-listing is the practice where foreign and multinational firms list their companies on a United States stock exchange. ${ }^{339}$ These companies usually cross-list with the aid of American Depository Receipts (ADRs), which are a form of derivative securities. ${ }^{340}$ United States depository banks hold foreign securities in custody in the country of origin and convert all payments into United States dollars to receipt holders in the United States. Investors bear all the currency risk and pay fees to the depository banks. Foreign companies must also satisfy two requirements to list on a United States exchange. ${ }^{341}$ The first requirement is to arrange for a precise reproduction of settlement facilities as domestic securities with a transfer agent and registrar. ${ }^{342}$ The firm must also register with the SEC. ${ }^{343}$ To accomplish this, a firm must file a

\footnotetext{
${ }^{337}$ Judy Sarasohn, Coalition Targets Accounting Law, Wash. Post, Oct. 24, 2002, at A33, available at http://www.washingtonpost.com/ac2/wp-dyn?pagename=article\&contentId=A8481-2002Oct24\&notFound=true.

${ }^{338}$ Craig Doidge et al., Private Benefits of Control, Ownership, and the Cross-Listing Decision 1 (European Corp. Governance Inst., Working Paper No. 77/2005, 2005), available at http://papers.ssrn.com/sol3/papers.cfm?abstract_id=668424.

${ }^{339}$ John C. Coffee Jr., Racing Towards the Top?: The Impact of Cross-Listings and Stock Market Competition on International Corporate Governance, 102 CoLUM. L. REV. 1757, 1757 (2002).

${ }^{340}$ Cally Jordan, International Cross-Listing and Bonding: The Chameleon Effect 1 (Sept. 13, 2004) (unpublished manuscript, on file with University of Florida College of Law). ADRs were developed by JP Morgan in 1927. Stephen R. Foerster \& G. Andrew Karolyi, The Effects of Market Segmentation and investor Recognition on Asset Prices: Evidence from Foreign Stocks Listing in the United States, 54 J. FIN. 981, 983 (1999), available at http://www.cob.ohio-state.edu/fin/faculty/karolyi/papers/JF1999.pdf. They were created as a method for investors to register and earn dividends on non - United States stock. Id.

${ }^{341}$ Foerster \& Karolyi, supra note 340.

${ }^{342} I d$.

${ }^{343} I d$.
} 
registration statement and supply an annual report on a Form $20-\mathrm{F}$ with a reconciliation of financial accounts performed under the requirements of GAAP. ${ }^{344}$

\section{Benefits of Cross-Listing}

The benefits of foreign and multinational companies cross-listing include "the increased ability to raise equity, growth of the firm's shareholder base, increased liquidity, lower cost of capital, and greater visibility and prestige." ${ }^{345}$ Another potential benefit for a firm cross-listing could be that United States investors would identify which new and innovative firms are likely to succeed. ${ }^{346}$ The cost of listing in the United States, according to reports by managers, is very small when compared to the benefits. ${ }^{347}$ Some scholars contend that "the primary benefit of cross listing involves voluntary submission to the U.S. disclosure and liability regimes, which may send a signal of firm quality and thereby reduce capital costs." ${ }^{348}$ The number of foreign and multinational companies cross-listing on a United States exchange has increased tremendously since the early 1990's. ${ }^{349}$ For example, the number of firms cross-listing on the New York Stock Exchange (NYSE) had more than quadrupled to 471 firms as of October, $2002 .^{350}$

\section{Costs of Cross-Listing}

\footnotetext{
${ }^{344} \mathrm{Id}$.

${ }^{345}$ Doidge et al., supra note 338, at 1 (citing surveys done by Karolyi in 1998 and 2004; Claessens, Klingebeil, and Schmukler in 2002; Benos and Weisbach in 2004; these surveys evaluate over one hundred and fifty studies that examine the decision to cross-list shares on a foreign market).

${ }^{346}$ Christopher Woo, The Effects of Sarbanes-Oxley on Foreign Private Issuers 4 (unpublished manuscript, on file with Harvard Law School), available at http://www.law.harvard.edu/programs/pifs/pdfs/christopher_woo.pdf.

${ }^{347}$ Craig Doidge et al., Why are foreign firms listed in the U.S. worth more? 1 (National Bureau of Economic Research, Working Paper No. 8538, 2003), available at http://jfe.rochester.edu/02367.pdf.

${ }^{348}$ Perino, supra note 10 (Citing Oren Fuerst, A Theoretical Analysis of Investor Protection Regulations: Argument for Global Listing of Stocks (Sept. 10, 1998) (unpublished paper, on file with author)).

${ }^{349}$ Kees G. Koedijk \& Mathijs A. van Dijk, The Cost of Capital of Cross-Listed Firms 2 (Erasmus Research Institute of Management, Working Paper No. ERS-2002-99-F\&A, 2002), available at http://www.business.uts.edu.au/qfrc/conferences/qmf2002/VanDiji_M.pdf.

${ }^{350}$ Id. at 2.
} 
Major costs of listing include "the disclosure standard, the requirement of accounting reconciliation, the direct cost in time and money associated with a United States listing, and the fear of liability." ${ }^{, 351}$ Whenever the firm wants to buy another company it must follow the United States disclosure and procedural rules, rather than the law of their respective country of domicile. $^{352}$ There are costs to list on a United States exchange including a listing fee for registration with the SEC and other associated costs for the necessary paperwork. ${ }^{353}$ Additional costs also include "increases in directors' and officers' liability insurance, accounting and legal fees, and board compensation (as board members are given increased responsibility and may be subjected to higher risk)." ${ }^{354}$ One recent study estimated that "public companies as a group would spend $\$ 2.5$ billion on information technology and related consulting in order to comply with the Act's internal control requirements.",355

\section{Effect of SOX on Cross-Listing}

SOX has had an effect on the decision of foreign and multinational firms to cross-list on a United States exchange. ${ }^{356}$ There are many companies that are hesitant to cross-list due to the regulations imposed by SOX. ${ }^{357}$ Porsche has decided not to list, citing "problems with SarbanesOxley, and has announced that it will not change its decision even after the proposed exemptions." 358 Companies such as the Benfield Group have chosen to list in London instead of listing on a United States exchange stating that the "London Stock Exchange has been quite openly using the regulatory hurdles associated with the Sarbanes-Oxley Act as a marketing

\footnotetext{
${ }^{351}$ Woo, supra note 346, at 7 (citing James A. Fanto \& Roberta S. Karmel, A Report on the Attitudes of Foreign Companies Regarding a U.S. Listing, 3 STAN. J.L. BUS. \& FIN. at 64, 69 (1997)).

${ }^{352}$ Siegel, supra note 9.

${ }^{353}$ Foerster \& Karolyi, supra note 340, at 984.

${ }^{354}$ Perino, supra note 10.

${ }^{355}$ Id. (quoting Eileen Colkin Cuneo, Y2K Again? Say It Ain't So, INFORMATIONWEEK.COM, May 19, 2003, at 20).

${ }^{356}$ Woo, supra note 346, at 19.

${ }^{357} \mathrm{Id}$.

${ }^{358} I d$.
} 
wedge against U.S. registration and listing. " ${ }^{359}$ The letter, written by the Benfield Group to the SEC, also stated thatSOXas led to "foreign regulators, companies and media questioning the right of Congress to change the rules for non-U.S. listed companies 'in the middle of the game." "360 William Donaldson, Chairman of the SEC, made the following statement in a speech in London:

\begin{abstract}
We also seek to have a listing in the U.S. to signify to investors throughout the world that this company is willing to make the investment needed to meet these standards. Companies who choose not to come to the United States may meet those same standards - but our registrants have taken the extra step of telling the world that they are up to the challenges that accompany a U.S. listing. ${ }^{361}$
\end{abstract}

In that same speech, however, he also states "the SEC has worked from its earliest days to accommodate foreign issuers" and "The SEC remains committed to a level playing field for all its issuers, foreign and domestic alike.",362

\title{
B. Influence of SOX on Corporate Governance Standards Worldwide
}

The success of Sarbanes-Oxley can also be seen in the influence which the Act has had on corporate governance standards abroad. Many countries are using Sarbanes-Oxley as a model for implementing their own regulations. ${ }^{363}$ South Korea has implemented regulations for CEO certifications of company financial reports. ${ }^{364}$ Companies in South Korea must get "CEOs to swear to the accuracy of their company's financial statements, to present consolidated financial sheets of affiliated firms, and to set up a 'firewall', separating auditing and consulting businesses." ${ }^{\text {365 }}$ Australia, even after rejecting it at first glance, is now considering using SOX as

\footnotetext{
${ }^{359}$ Letter from Darla Stuckey, Corp. Secretary, NYSE, to Jonathan G. Katz, Secretary, Sec. Exch., Comm'n (Feb. 21, 2003) (on file with the Sec. Exch. Comm'n), available at http://www.sec.gov/rules/proposed/s70203/dcstuckey1.htm.

${ }^{360}$ Stuckey, supra note 359.

${ }^{361}$ Donaldson, supra note 25.

${ }^{362} I d$.

${ }^{363}$ Patton Boggs, LLP, supra note 308.

${ }^{364} \mathrm{Id}$.

${ }^{365}$ Lucci, supra note 151, at 244.
} 
a model and holding executives liable for the credibility of financial statements. ${ }^{366}$ Canada introduced a bill with very similar terms as SOXbut the regulations imposed by the bill are not nearly as comprehensive. ${ }^{367}$ A commentator from the United Kingdom even stated that SOX “looks certain to become the benchmark against which every other jurisdiction's corporate governance rules are tested., 368

\section{CONCLUSION}

In conclusion, SOX is a very controversial act that has many companies, foreign and multinational, asking for relief. SOX was enacted to deter corporate corruption in the United States, but has had a global impact There are many regulations imposed by SOX that conflict with international corporate governance standards and also regulations of individual countries outside the United States.

The extraterritoriality of SOX is a hotly debated topic. It will continue to be until either the SEC decides to exempt all foreign and multinational companies listing on a United States exchange from regulation or there is a convergence of SOX and international corporate governance regulations. Companies can only look to the legislative history of SOX and past decisions to see how SOX may affect them in the future.

The SEC has the power to grant exemptions to foreign and multinational firms, but doing so may invoke an outcry from domestic firms. If the SEC is not applying the same rules, it will destroy the even playing field that the SEC desired to create by enacting SOX. The effectiveness of SOX will be greatly weakened if firms will be exempted form certain regulations, just because

\footnotetext{
${ }^{366} I d$.

${ }^{367}$ See Julius Melnitzer, Sarbanes-Oxley Creeps Across Border: Canada Debates Need for SEC-Type Governance Rules and Regulations, 2/03 CORP. LEGAL TIMES 33 (COL. 1), Feb. 2003. It imposes rule on attorneys to report violations, but it is not as stringent as SOX. $I d$. The measures were introduced to stimulate the amount of investment to Canadian Capital markets. Id.

${ }^{368}$ Patton Boggs, LLP, supra note 308 (quoting Andrew Sawers, Company Law, Act Brings Greater Accountability, FIN. DiRECTOR (U.K.), Oct, 1, 2002).
} 
they move their headquarters outside of the United States or move a majority of their operations outside of the United States.

Legislation will not be enough, by itself, to swing the pendulum in the right direction. Companies, both foreign and domestic, must take personal responsibility in restoring investor confidence in the United States securities and capital market and also the global securities market. SOX is a step in the right direction, but companies must do everything in their power to deter corruption and restore confidence in markets where there is none. 